\title{
Forward-Looking and Backward-Looking Taylor Rules: Evidence from Pakistan
}

\section{Nadia Tahir}

\begin{abstract}
This study uses the forward-looking rule and backward-looking Taylor rule to investigate the conduct of monetary policy in Pakistan during 1971-2011. We compare the pre- and post-reform periods, and find that the estimates obtained using the generalized method of moments indicate that no interest rate rule was being followed. This explains the inability of monetary policy to control inflation and minimize the output gap. Although monetary policy was not very active in the pre- and post-reform periods, the post-reform quarterly data show some interest rate inertia and smoothing. Monetary policy was less accommodating of the cyclical nature of the output gap. We conclude that the behavior of the State Bank of Pakistan was not very different under forward-or backward-looking rules.
\end{abstract}

Keywords: Taylor rule, forward-looking behavior, backward-looking policy, monetary policy, generalized method of moments.

JEL classification: C22, E52, E58.

\section{Introduction}

Pakistan's inflation rate fluctuated widely between 3 and 27 percent during 1971:Q1-2011:Q4. The average inflation rate was 9.5 percent with a standard deviation of 6 percent. With this highly volatile rate, every episode of high inflation was followed by a tamed inflationary regime. However, the inflation rate and growth rate followed a mixed trend: the high inflationary environment of the 1980s was accompanied by high growth, but after 1990, the regime yielded contrary results. The State Bank of Pakistan (SBP) introduced several reforms in the financial sector during this time, which influenced monetary policy. As a result, the SBP made some adjustments to the interest rate but found itself still facing fiscal dominance. Although these policy changes brought about some success in restraining inflation, the instability continued.

\footnotetext{
* Associate Professor of Economics, University of Central Punjab, Lahore, Pakistan
} 
In this paper, we ask how monetary policy is conducted in such an environment. Does it rely on discretion or the use of a sophisticated rule? In this context, discretion can be seen as "muddling through." Lagged reactions may exacerbate an inflationary situation whereas rules are determined and set such that the central bank follows a particular rule regardless of the situation. However, this rigidity limits policy options and any deviation from the set path can result in short-run fluctuations.

Taylor's (1993b) rule relates movements in the interest rate to the inflation rate and output gap. The rule is simply an equation indicating that the larger the coefficients, the more aggressive monetary policy will be. Taylor's rule approximates the path of the quarterly federal funds rate during 1987:Q1-1992:Q3. The debate that followed this study theorized a rule-based monetary policy as the only mandate of a central bank. The effectiveness of the central bank was judged on the basis of policy reaction functions in controlling inflation. Taylor (2000) clarifies that a monetary policy rule is nothing more than a contingency plan that describes as precisely as possible the circumstances in which a central bank can change the instruments of monetary policy. Taylor's earlier (1999a) study advocates a historical rather than model-based approach to monetary policy, arguing that historical rules evolve slowly but allow the separation of policy influences. Subsequently, Rudebusch (2002) has held that monetary policy sluggishness or gradualism is an illusion.

Many studies have raised questions about adopting rules. Goodhart $(1984,1991)$ notes that rules are rigid: they fail to address the complexities of changing circumstances and tend to collapse in extraordinary circumstances. The targets of a government with damaged credibility become irrelevant, leaving the field open for economic indicators to guide policy. An important question relates to the determination of the interest rate. Is the Taylor rule based on past movements in inflation or on the expected inflation rate? Kerr and King (1996), Bernanke and Woodford (1997), and Clarida, Galí, and Gertler $(1997,1998,2000)$ suggest that the future inflation rate acts as a policy guide for central banks to help them avoid inconsistencies. When households and businesses start to expect higher inflation in the economy, this generates more inflation. In this case, the past inflation rate is not a good guide for the monetary authority.

Taylor (1993a, 1993b) points out that numerous generalizations can make these rules more responsive but also more complex. He gives the example of estimating the expected inflation rate where one would need to 
use futures markets, the term structure of interest rates, and various surveys. Problems inherent in measuring the output gap-such as predictions about productivity, labor force participation and changes in the natural rate of unemployment-mean that the rule must be kept simple.

Mishkin (1996) argues that it is dangerous to invariably associate monetary policy easing or tightening with a rise or fall in short-term nominal interest rates because the nominal interest rate does not always pass through to the real interest rate. Other asset prices, e.g., stock prices and land prices, are also based on information about the central bank's monetary policy stance. Open market operations are also an important tool for monetary policy that works by increasing inflation and smoothing other asset prices, thus increasing output.

Price stability is crucial for business decisions because inflation can affect economic growth adversely. Many central banks pursue a strategy of proactively raising interest rates to prevent a rise in inflation in an overheated economy. The policy's success requires the monetary authority to make an accurate assessment of the timing and effect of its policies on the economy. Woodford (2000) explains the problems of forecasting private sector expectations when determining the future rate of inflation. In forward-looking models, an optimal policy depends on the path of a target that evolves over time. These principles are applicable only in a controlled environment; this does not exist in the case of monetary policy, which requires the private sector to be able to respond in the presence of shocks.

This paper aims to address the following questions. How does the SBP conduct monetary policy to achieve price stability and minimize the output gap? Do interest rate changes reasonably approximate the inflation rate in Pakistan? If so, do they follow the Taylor rule based on past or future inflation?

Section 2 provides an overview of monetary policy in Pakistan. Section 3 presents an analytical framework and specifies the Taylor rule for Pakistan; it also describes the data used and their sources. Section 4 carries out estimations using the annual and quarterly time series, subdividing the latter into five monetary regimes to examine the relative autonomy of the SBP. We apply the Chow test to ascertain the presence of any structural breaks across regimes and differences in policy response. Section 5 traces the rules path and estimates the social loss function. Section 6 presents some concluding observations. 


\section{Monetary Policy in Pakistan: An Overview}

The SBP became relatively autonomous in the early 1990s with the onset of structural adjustment and liberalization reforms. During 1989-92, Pakistan implemented the World Bank's Financial Sector Deepening and Intermediation Project. To support this reform program, the IMF initiated a three-year structural adjustment program (see Janjua, 2004). This section compares the conduct of monetary policy in the pre-reform and postreform periods over 1971-2011.

We distinguish between different monetary regimes on the basis of changes in leadership (governor) at the SBP. Subdividing the quarterly data series into pre- and post-reform regimes enables us to look closely at the stability and reaction function of monetary policy in periods of relative autonomy. The post-reform period is also subdivided into five regimes on the basis of governors' tenures, though not necessarily coinciding with changes in the political regime. It is interesting to note that most of these governors were appointed by caretaker regimes (see Appendix). The rapid turnover of political regimes makes it difficult to apply any sophisticated statistical analysis in order to understand the issue of the SBP's autonomy.

The duration of the SBP governor's tenure has not always been constant. For the sake of statistical analysis, therefore, we adjust some overlapping tenures. I. A. Hanfi assumed the governor's office on 17 August 1988. Following his resignation, Kasim Parekh was appointed governor; his term ended on 30 August 1990, after which Hanfi was reappointed from 1 September 1990 to 30 June 1993. Given the small number of observations for this period, we merge Parekh's tenure with Hanfi's second tenure. Thus, the period 1989:Q1-1993:Q3 is identified as Hanfi's tenure. The second regime under Mohammad Yaqub lasted two full terms from July 1993 to November 1999. Ishrat Husain, who followed, also completed two full terms from 2 December 1999 to 1 December 2005. Shamshad Akhtar, the SBP's first woman governor, succeeded Husain from 2006:Q1 to 2008:Q3, while the present regime has already seen three governors (Salim Raza, Shahid Kardar, and the present governor, Yasin Anwar).

Under the State Bank of Pakistan Act, the scope for independent action increased incrementally, although the SBP has been perceived as acting more or less autonomously depending on the governor's strength of personality. The first noteworthy attempt to gain some autonomy for the SBP was made by S. U. Durrani at the 23rd general board meeting on 18 September 1971. The effort was short-lived as the SBP soon became 
virtually attached to the finance ministry. On 28 November 1989, Hanfi informed the board that the SBP had no effective control over monetary policy; he went on leave and eventually resigned in protest. Hanfi was not the only governor who had to resign from office. The period 1986-93 was highly destabilizing not only in political terms and changes in government, but also for the SBP.

The first formal step toward autonomy was taken in 1993 when the SBP was detached from the finance ministry (Janjua, 2004). Several significant changes took place during this period of relative autonomy (1989:Q1-2011:Q4). In 1991, permission to open new commercial banks was granted. Nonetheless, Hanfi's policies, similar to those of his predecessor, were less active in both directions: the SBP neither stabilized prices nor tried to reduce the output gap. The finance ministry continued to make decisions even on routine matters of the SBP.

In August 1993, the caretaker government of Prime Minister Moeen Qureshi recognized the need for the central bank's autonomy to improve macroeconomic management. It proposed the separation of fiscal and monetary management. This was a period of low external financial assistance and mounting debt servicing. While a tight monetary policy may not have been the ideal choice, it was the only option left.

Under Yaqub's governorship during this period, the SBP's autonomy was never fully absorbed. A new government followed the caretaker regime and the Monetary and Fiscal Policy Coordination Board was formed, allowing the finance ministry back in the driver's seat. Yaqub resigned three times from the governorship because of his commitment to financial liberalization. In 1995, maximum lending rates-except on concessionary finance schemes-were abolished. Minimum lending rates were abolished in 1997. These price ceilings and floors were the main reason for the prevailing market rigidities and distortions.

The Husain regime was no different from that of Hanfi in incorrectly estimating the state of the economy. Monetary policy remained discretionary. The SBP's autonomy was diluted once again in the name of better financial regulation. The President became responsible for appointing the bank's governor while the federal government appointed its deputy governors.

Under Shamshad Akhtar, the SBP prepared a ten-year strategy paper on banking sector reforms. The paper recommended making 
changes in the State Bank of Pakistan Act to redefine and strengthen the SBP's role in making and executing monetary policy. It also sought a clearcut role for the central bank in advising the government on fiscal policy and domestic debt management (SBP, 2009). However, Akhtar's term ended before any concrete steps could be taken.

Governors are appointed initially for a period of three years, which may be extended for another three years. Since Akhtar's departure, the actual tenures have become shorter. Some reforms have been introduced, such as the separation of liquidity and debt management, a corridor framework for the overnight money market rate, and the institution of a representative monetary policy committee to improve transparency credibility. The frequency of monetary policy announcements has also increased. However, the changes required in the State Bank of Pakistan Act to ensure the central bank's autonomy have not taken place (see SBP, n.d.).

\section{Analytical Framework}

This section describes the framework within which we estimate a Taylor-type rule for Pakistan's economy.

\subsection{The Taylor Rule}

Taylor (1993b) explains monetary policy as an interest feedback rule, where the percent federal funds rate $\left(i_{t}\right)$ is a function of the percent inflation rate $\left(\pi_{t}\right)$ and the percent change in output gap $\left(y_{t}\right)$

$$
i_{t}=0.04+1.5\left(\pi_{t}-0.02\right)+0.5\left(y_{t}-y_{t}^{*}\right)
$$

If the central bank follows this rule strictly, it must have a 2 percent inflation and interest rate rule. The federal funds rate rises when there is an increase in the inflation rate from 2 percent or when real GDP exceeds the trend. When the central bank achieves its inflation and real GDP targets, then the federal funds rate will be equal to 4 percent. The Taylor rule is considered a fairly good explanation of US monetary policy and a prescription for desirable policy rule or an indicator for assessing policy behavior (Woodford, 2001).

Buzeneca and Maino (2007) argue that developing countries apply a rule-based monetary policy more intensively because of their shallow markets. Taylor's (2000) rule-based policy is a better instrument for developing countries because of velocity shocks. Monetary aggregates are preferable only if measuring the real interest rate is difficult or if major 
shocks to investment occur. Orphanides and Wieland (2013) modify the Taylor rule and give it a more generalized form as follows:

$$
i_{t}=i_{t-1}+0.5\left(\pi_{(t+3 \mid t)}-\pi^{*}\right)+0.5\left(q_{(t+2 \mid t)}-q_{(t+2 \mid t)}^{*}\right)
$$

where $i_{t}$ stands for the federal funds rate set by the central bank, $\pi$ denotes the inflation rate, $\pi^{*}$ denotes the target inflation rate, $q$ stands for the GDP growth rate, $q^{*}$ denotes potential GDP, $t$ is a time subscript representing one quarter, and $t+2,3$ indicates the second and third quarter forecasts, respectively. This equation shows that the central bank adjusts its policy rate based on deviations in the forecasted inflation rate from the target inflation rate and on deviations in forecasted GDP growth from the estimated potential GDP growth. The regression coefficient 0.5 implies that a one-percentage point deviation in the target inflation rate or output growth requires the policy rate to be adjusted by 50 points. This can be converted into a simple formula for estimation:

$$
r=r *+C \pi(\pi-\pi *)+C Y y
$$

where $r$ is the real interest rate, and $C \pi$ and $C Y$ are the coefficients on the policy rules.

The real interest rate is calculated as $r=i-\pi$, after substituting the value of $r$ in the above equation and obtaining

$$
i=\left(r^{*}-C_{\pi} \pi\right)+\left(1+C_{\pi}\right) \pi+C_{y} y_{t}
$$

where $\left(r^{*}-C_{\pi} \pi^{*}\right)=C$

$$
i=C+\left(1+C_{\pi}\right) \pi+C_{y} y_{t}
$$

This rule assumes that the real interest rate is adjusted around the target rate, and the inflation rate and output gap deviate from the target, which is assumed to be $\pi^{*}$ and 0 . The equation then takes the form

$$
\begin{aligned}
& r=C+C_{\pi} \pi+C_{y} y_{t} \\
& C>0,\left(1+C_{\pi}\right) \geq 1, C_{y} \geq 0
\end{aligned}
$$

If monetary policy follows a Taylor rule-like prescription, the intercept value $(C)$ has to be positive and the inflation target $\left(1+C_{\pi}\right)$ greater than 1 . This means that the interest rate has a positive relationship 
with inflation and shifts in the same direction with a change in inflation. The output gap $\left(C_{y}\right)$ has to be positive and greater than 0 .

$$
i=1+1.5 \pi+0.5 \mathrm{y}
$$

In a strict sense, these values must be $1,1.5$, and 0.5 . Deviations from these values explain the behavior of monetary policy. The low value of R-squared indicates a discretionary monetary policy and the low response of the central bank in controlling inflation (Tchaidze, 2001).

Clarida et al. (2000) have criticized the Taylor rule where the federal funds rate is a function of lagged inflation and the output gap. They suggest that the conduct of monetary policy changes with the shift in macroeconomic variables. Monetary policy rules must adjust the federal funds rate in accordance with expected inflation and output at their target rates. The central bank has not only to adjust the interest rate but also to predict the expected inflation rate. If there are expectations of high inflation, the central bank should take a proactive stance. In the authors' version of policy rules, the Taylor rule becomes a special case.

\subsection{Baseline Reaction Function}

Clarida et al (2000) formulate the following forward looking rule:

$$
r_{t}^{*}=r^{*}+\beta\left(E\left\{\pi_{t, k} \mid \Omega_{t}\right\}-\pi^{*}\right)+\gamma E\left\{x_{t, q} \mid \Omega_{t}\right\}
$$

$\pi_{t, k}$ is the annual inflation rate measured as the percentage difference in the price level between two time periods $t$ and $k . \pi^{*}$ is the target inflation rate, $x_{t, q}$ is the output gap measured as the percentage difference of the log of real GDP, $E$ is the expectations operator, $\Omega_{t}$ is the information operator, $r_{t}^{*}$ is the federal funds rate, and $r^{*} \mathrm{~s}$ the target nominal interest rate for targeted inflation and the output gap.

\subsection{Implied Real Rate Rule}

Clarida et al (2000) consider following implied real rate rule for the real interest rate target $r r$ :

$$
\begin{aligned}
& r r_{t}^{*}=r r^{*}+(\beta-1)\left(E\left\{\pi_{t, k} \mid \Omega_{t}\right\}-\pi^{*}\right)+\gamma E\left\{x_{t, q} \mid \Omega_{t}\right\} \\
& r r_{t}^{*}=r_{t}-E\left\{\pi_{t, k} \mid \Omega_{t}\right\} \text { and } r r^{*}=r^{*}-\pi^{*} \quad \text { represent the real }
\end{aligned}
$$
interest rate, which is stationary and determined by nonmonetary factors. 
The benchmark rate for $\beta$ is 1 and for $\gamma$ is 0 . The sign and magnitude both play an important role. When $\beta>1$, the interest rate rule tends to stabilize the economy; when $\beta \leq 1$, the interest rate rule is likely to destabilize or accommodate shocks to the economy. If $\gamma>1$, the economy is likely to be stabilized and when $\gamma \leq 1$, the economy will tend to stabilize. In each period, the central bank adjusts the funds rate as a function of the gap between the current target rate and a linear combination of past values of the interest rate.

$$
r_{t}=\rho(L) r_{t-1}+(1-\rho) r_{t}^{*}
$$

Continuing to follow Clarida et al (2000), inserting an interest ratesmoothing equation into the target equation yields

$$
r_{t}=(1-\rho)\left\{r r^{*}-(\beta-1) \pi^{*}+\left\{\beta \pi_{t, k}+\gamma x_{t, q}\right\}+\rho(L) r_{t-1}+\varepsilon_{t},\right.
$$

Clarida et al (2000) assume the error term to be a linear combination of forecasted errors and is considered orthogonal, yielding:

$$
E\left\{r_{t}-(1-\rho)\left\{r r^{*}-(\beta-1) \pi^{*}+\left\{\beta \pi_{t, k}+\gamma x_{t, q}\right\}+\rho(L) r_{t-1}\right\} z_{t}=0(10)\right.
$$

where $z_{t}$ is a set of instruments-measured by the generalized method of moments (GMM) - with an optimal weighting matrix that accounts for possible serial correlation. When the number of instruments equals more than four restrictions, we can test the overidentification assumption. We then impose the restriction that the sample average should equal the real equilibrium interest rate. All other assumptions are the same as in Clarida et al. (2000).

\subsection{Method of Estimation}

We use the GMM to estimate the Taylor rule for Pakistan. This method is applied to a dataset where the shape of the distribution is not known (see Hansen, 1982). Given that GMM estimators are considered consistent, asymptotically normal, and efficient, we can replace the population parameter moment condition with its sample analogy. We also assume that the orthogonality condition holds, implying that the instruments used are exogenous and uncorrelated with the error term. Should the number of instruments exceed the number of parameters, there will be no unique solution; we would then assume an objective function by introducing a weighting matrix. Roodman (2009) also points out that, when 
the GMM uses weak instruments or too many instruments, its distribution is not reliable.

\subsection{Specifications and Data}

We use both annual and quarterly data to estimate the SBP's policy stance. The annual dataset extends from the fiscal year 1971 to the fiscal year 2011. The inflation rate is measured in terms of the GDP deflator, and the log of real GDP is used to measure the output gap as the percent difference between actual and potential GDP. Potential GDP is measured using the Hodrick-Prescott (HP) filter at power 4 (see Ravn \& Uhlig, 2002). The discount rate is used as the interest rate in light of Harvey and Jaeger (1993) and Harvey and Trimbur's (2008) criticism that the HP filter uses an inappropriate smoothing constant. Our experiment shows that a default value of $16,000 \mathrm{p}^{\wedge} 4$ best explains the trend in this series.

First, we test the traditional Taylor rule equation, which is a linear combination of the interest rate, inflation rate, and output gap. We then test the same rule incorporating the modifications given in Clarida et al. (2000), using the GMM. We use four lags for the inflation rate and growth rate in broad money supply, the difference between the short-run and long-run interest rate spread, and the consumer price index (CPI) interest rate as instruments. These lags are selected on the basis of Hansen's J-statistic, which is used to test over-identified specifications. The difference-inHansen test is applied to check the orthogonality of weak instruments.

The second dataset, the quarterly data series, spans the calendar years 1970:Q1 to 2011:Q4. All data are taken from the International Monetary Fund's International Financial Statistics (2011). For this dataset, we use the quarterly inflation rate measured on the basis of the percent change in the CPI on a year-to-year basis. Since Pakistan does not yet have official quarterly estimates for GDP, we use the index of large-scale manufacturing as a proxy for output growth. Although this is a source of specification bias, various authors have used the same proxy due to the same constraint. ${ }^{1}$

The HP filtering technique is used to remove the trend when computing potential GDP. This is a standard data de-trending technique

\footnotetext{
${ }^{1}$ Khan and Schimmelpfenning (2006) use an interpolated series of nominal and real GDP and a large-scale manufacturing index to measure economic activity. Ahmad and Ahmed (2006) also use the quantum index of industrial production as a proxy for GDP. They cite Shanmugam, Nair, and Li (2003) and Nell (2000/01) with regard to using these proxies.
} 
that yields robust results. The call money rate, rather than the discount rate, is taken as the interest rate, given that the SBP used the fixed discount rate as a policy measure in the pre-reform period. The use of adjustments in the discount or policy rate arose after Hanfi's tenure.

\section{Estimation}

Figure 1 shows the cyclical nature of the relationship between the output gap, inflation rate, and interest rate. Even in the absence of shocks, these fluctuations prove to be persistent and self-fulfilling.

Figure 1: Cyclical behavior of output, inflation, and interest rate in Pakistan

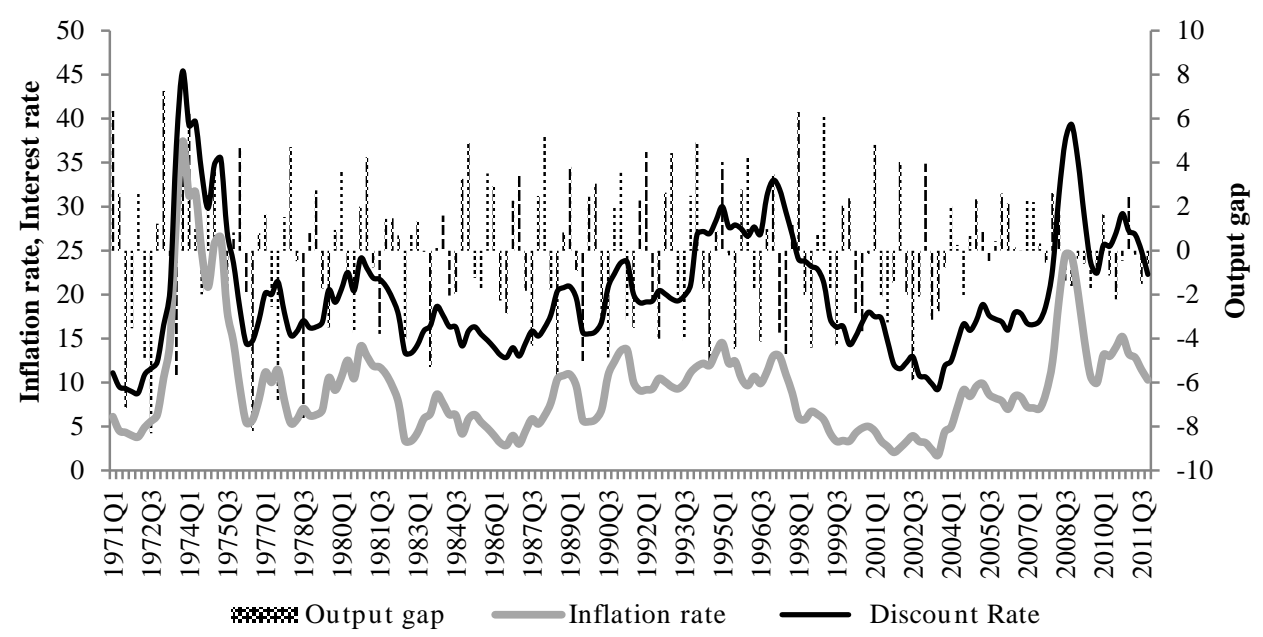

\subsection{Forward-Looking Monetary Policy Rules}

We estimate the Taylor rule for Pakistan by using the GMM to analyze annual data for 1971-2011 on the interest rate, inflation rate, output gap, and interest rate-smoothing constant $p$. We then estimate the same model using quarterly data for 1971:Q1-2011:Q4, subdividing the data into the reform period 1989:Q1-2011:Q4. The target horizon used is one year for the annual data and one quarter for the quarterly data. The results are summarized in Table 1. Clarida et al. (2000) find that a value of less than 1 for the inflation rate indicates the failure of monetary policy in controlling inflation. It implies that the monetary policy was poorly designed as a result of incorrect estimates of the state of the economy. When $\beta \leq 1$, the interest rate rule tends to destabilize or accommodate shocks to the economy. 
Table 1: Forward-looking monetary policy rules (baseline results)

\begin{tabular}{lcccc}
\hline Period & $\begin{array}{c}\text { Inflation } \\
\text { rate }\end{array}$ & $\begin{array}{c}\text { Output } \\
\text { gap }\end{array}$ & Constant & $\begin{array}{c}\text { H-J } \chi^{2} \\
\text { P-value }\end{array}$ \\
\hline 1971-2011 (GMM) & $0.319^{* *}$ & $-0.143^{*}$ & $1.816^{* * *}$ & 8.07152 \\
& $(0.0063)$ & $(0.077)$ & $(0.0764)$ & $(0.1523)$ \\
1971:Q1-2011:Q4 (GMM) & $0.021^{* *}$ & $0.030^{*}$ & $1.90^{* * *}$ & 21.35 \\
& $(0.007)$ & $(0.0197)$ & $(0.0964)$ & $(0.0003)$ \\
1989:Q1-2011:Q4 (GMM) & $0.049^{* *}$ & $0.032^{*}$ & $1.637^{* * *}$ & 9.52302 \\
& $(0.010)$ & $(0.014)$ & $(0.160)$ & $(0.0493)$ \\
\hline
\end{tabular}

Note: Standard errors are reported in parentheses. The set of instruments includes four lags for the inflation rate, short-long spread, CPI rate, and M2 growth rate. ${ }^{*} \mathrm{p}<0.05,{ }^{* *} \mathrm{p}$ $<0.01,{ }^{* * *} \mathrm{p}<0.001$.

Source: Author's calculations.

The value of the coefficient of the inflation rate is 0.32 with a standard error (SE) of 0.0063 , i.e., below 1 and significant. The output gap is negative and has a value of -0.14 with an SE of 0.07 . Hansen's J chi-square value is 8.07152 with a p-value of 0.1523 , indicating interest rate inertia during 1971-2011. We conclude that there is no adjustment to the interest rate when the inflation rate is rising or when output deviates above the target. The absolute values of the output gap estimates do not justify the tightening of monetary policy.

The GMM results show that the SBP did not resort to an aggressive policy in order to control inflation. The central bank did not actively reduce the output gap and inflation rate with adjustments in the interest rate, which is important for influencing aggregate demand. We conclude that the SBP's monetary policy during 1971-2011 was discretionary and less active. All the variables are significant but their signs are not as expected. The coefficient of the output gap has a negative sign for the annual data, which is not in accordance with the Taylor rule or its modification by Clarida et al. (2000).

In the case of the quarterly data (1971:Q1-2011:Q4), which includes variables such as the CPI inflation rate, a large-scale manufacturing production index as a proxy for GDP, and the interest rate, the coefficient of the expected inflation rate is below unity (0.021, SE 0.007), i.e., far less than in the reform period $(0.049$, SE 0.10). Although significant, the low value indicates a chaotic monetary policy. The coefficient of the output gap is significant and positive, which points to the sensitivity of the cyclical variable, but it also remains low and is the same (0.03, SE 0.020). The value 
of the smoothing parameter $p$ remains low (0.0003 and 0.04, respectively), implying that there is no interest rate inertia.

\subsection{Backward-Looking Monetary Policy Rules}

Taylor (1993a) presents the coefficient of the backward-looking inflation rate $\left(1+C_{\pi}\right)>1$ as a necessary stability condition. If the coefficient has a value of 1.5 , the response of the central bank matches the historical trend. In Table 2, we use ordinary least squares (OLS) to estimate the Taylor rule because Taylor (1993a) assumes a linear relationship between the interest rate and inflation rate and deviations in GDP. Since there is an indication of autocorrelation, we apply the augmented Dickey-Fuller (ADF) and L-Jung tests to the residuals; the tests show that the residuals are consistent. The specification for the Taylor rule computed on the basis of annual time series data (1971-2011) and employing the past behavior of monetary policy shows that the SBP has not followed the Taylor rule in controlling inflation in Pakistan.

\section{Table 2: Backward-looking monetary policy rules}

\begin{tabular}{lcccc}
\hline & & & & $\begin{array}{c}\text { Adjusted R-sq. } \\
\text { (AC) }\end{array}$ \\
Period & Inflation rate & Output gap & Constant & ADF test \\
\hline 1971-2011 (OLS) & $0.240^{* *}$ & $-0.672^{*}$ & $6.099^{* * *}$ & 0.449 \\
& $(0.0052)$ & $(0.167)$ & $(0.617)$ & $(1.08)$ \\
& & & & -3.745 \\
1971:Q1-2011:Q4 (OLS) & $0.066^{* *}$ & $0.096^{*}$ & $1.633^{* * *}$ & 0.65 \\
& $(0.022)$ & $(0.039)$ & $(0.433)$ & $(2.33)$ \\
& & & & -15.02 \\
1989:Q1-2011:Q4 & $0.392^{* *}$ & $0.150^{*}$ & $5.280^{* * *}$ & 0.302 \\
& $(0.063)$ & $(0.0965)$ & $(0.644)$ & $(0.678)$ \\
& & & & -4.39 \\
\hline
\end{tabular}

Note: Standard errors are reported in parentheses. $\mathrm{AC}=$ auto correlation, $\mathrm{ADF}=$ augmented Dickey Fuller test. ${ }^{*} \mathrm{p}<0.05,{ }^{* *} \mathrm{p}<0.01,{ }^{* * *} \mathrm{p}<0.001$.

Source: Author's calculations.

Our OLS results confirm those of Malik and Ahmed (2010). The coefficient of the inflation rate is 0.24 with an SE of 0.0052 . The magnitude of the inflation rate $(0.24)$ is less than 1.5 , implying a less responsive monetary policy. The output gap has a negative sign, which not only contradicts the Taylor rule but also indicates that the SBP decreased the interest rate during high inflation regimes or vice versa. The overall Rsquared value is low at 0.45 , implying that monetary policy is unsystematic. The OLS results are consistent and significant. 
When we apply the Taylor rule to the quarterly data using the large-scale manufacturing index as a proxy for real GDP, the magnitude is even smaller than for the annual data, indicating an even weaker monetary policy stance. However, the sign of the coefficient of the output gap is positive. Under the Taylor rule, a positive coefficient implies there is a high possibility that inflation will increase in the future; the adjustment between the output gap and interest rate reflects the use of a pre-emptive, cyclical policy. This is considered to be a short-run objective of growth without compromising long-term price stability in the economy.

Although the output gap is positive with respect to the real interest rate on the basis of the quarterly data, it is not significant and the residuals are autocorrelated. For robust results, we use an AR (1) model to eliminate the autocorrelation. We find there is a possibility of future inflation; the SBP appears to have preferred adopting a cyclical policy, giving precedence to short-run growth over long-run price stability. The coefficient is less than 0.5 , indicating a cyclical and less aggressive policy.

\subsection{Reform Period (Quarterly Time Series 1989:Q1-2011:Q4)}

Our results for this period show that the inflation rate coefficient is less than 1 at 0.392 . This means that the interest rate did not adjust fully to inflationary pressures in the economy and the SBP did not pursue a stable low-inflation objective. In other words, it did not exercise autonomy or practice "leaning against the wind" (Tchaidze, 2001). The coefficient of the output gap at 0.150 is positive, which shows that the increase in the output gap was cyclical and likely to increase the future inflation rate. However, as the value is low and insignificant, the output gap was not aggressive.

The overall R-squared value is very low at 0.302 , indicating a very weak policy stance and confirming that the SBP adopted a. The residuals are consistent as shown by the ADF test. These results are not different from those for the annual data series except for the output gap sign, which is positive but small. Table 3 summarizes the regime-wise results for the Taylor rule for the period 1989:Q1-2011:Q4 with backward-looking and forward-looking monetary policy rules.

\subsubsection{The Hanfi Regime 1989:Q1-1993:Q2}

In the forward-looking model, the low but positive coefficient of the output gap $(0.0182$, SE 0.005$)$ points to a sensitive, cyclical monetary policy. The coefficient of the inflation rate $(0.015$, SE 0.021$)$ indicates an insignificant 
and weak monetary policy stance, with the likelihood of a higher rate of inflation in the future. The high value of $p(0.47)$ shows a considerable degree of interest rate inertia. The backward-looking model yields an inflation rate coefficient that is less than 1 (-0.023, SE 0.105), indicating the lack of adjustment between the inflation and interest rates. Although its sign is different, it remains insignificant as in the forward-looking model. The relatively high value of R-squared indicates a systematic policy.

Table 3: Summary results for Taylor rule by monetary policy regime

\begin{tabular}{|c|c|c|c|c|c|}
\hline Regime & & $\begin{array}{c}\text { Inflation } \\
\text { rate }\end{array}$ & $\begin{array}{l}\text { Output } \\
\text { gap }\end{array}$ & Constant & $\begin{array}{c}\text { H-J } \chi^{2} \\
\text { P-value } \\
\text { R-sq. }\end{array}$ \\
\hline \multirow[t]{2}{*}{$\begin{array}{l}\text { Hanfi } \\
\text { 1989:Q1-1993:Q2 }\end{array}$} & GMM & $\begin{array}{l}0.015 \\
(0.021)\end{array}$ & $\begin{array}{l}0.0182^{* * *} \\
(0.0051)\end{array}$ & $\begin{array}{l}1.828^{* *} \\
(0.271)\end{array}$ & $\begin{array}{l}3.58 \\
(p=0.47)\end{array}$ \\
\hline & OLS & $\begin{array}{l}-0.023 \\
(0.219)\end{array}$ & $\begin{array}{l}0.068^{* *} \\
(0.209)\end{array}$ & $\begin{array}{l}0.358 \\
(0.384)\end{array}$ & 0.43 \\
\hline \multirow[t]{2}{*}{$\begin{array}{l}\text { Yaqub } \\
\text { 1993:Q3-1999:Q2 }\end{array}$} & GMM & $\begin{array}{l}0.0351 \\
(0.022)\end{array}$ & $\begin{array}{l}0.0124^{* *} \\
(0.004)\end{array}$ & $\begin{array}{l}1.966^{* * *} \\
(0.234)\end{array}$ & $\begin{array}{l}4.46555 \\
(p=0.35)\end{array}$ \\
\hline & OLS & $\begin{array}{l}0.250 \\
(0.188)\end{array}$ & $\begin{array}{l}0.021^{*} \\
(0.011)\end{array}$ & $\begin{array}{l}0.152 \\
(0.238)\end{array}$ & 0.17 \\
\hline \multirow[t]{2}{*}{$\begin{array}{l}\text { Husain } \\
\text { 1999:Q3-2005:Q3 }\end{array}$} & GMM & $\begin{array}{l}-0.0489^{*} \\
(0.034)\end{array}$ & $\begin{array}{l}0.012 \\
(0.021)\end{array}$ & $\begin{array}{l}2.01^{* * *} \\
(0.196)\end{array}$ & $\begin{array}{l}13.41 \\
(p= \\
0.009)\end{array}$ \\
\hline & OLS & $\begin{array}{l}0.154 \\
(0.1797)\end{array}$ & $\begin{array}{l}-0.0118 \\
(0.011)\end{array}$ & $\begin{array}{l}-0.186 \\
(0.186)\end{array}$ & 0.078 \\
\hline \multirow[t]{2}{*}{$\begin{array}{l}\text { Akhtar } \\
\text { 2005:Q4-2008:Q3 }\end{array}$} & GMM & $\begin{array}{l}0.030 * * * \\
(0.007)\end{array}$ & $\begin{array}{l}0.011 \\
(0.012)\end{array}$ & $\begin{array}{l}1.889 * * * \\
(0.123)\end{array}$ & $\begin{array}{l}0.888 \\
(p=0.93)\end{array}$ \\
\hline & OLS & $\begin{array}{l}0.162^{* * *} \\
(0.026)\end{array}$ & $\begin{array}{l}-0.008 \\
(0.006)\end{array}$ & $\begin{array}{l}0.117 \\
(0.701)\end{array}$ & 0.85 \\
\hline \multirow[t]{2}{*}{$\begin{array}{l}\text { Present regime } \\
\text { 2008:Q4-2011:Q4 }\end{array}$} & GMM & $\begin{array}{l}0.0119^{* * *} \\
(0.003)\end{array}$ & $\begin{array}{l}(-0.009) \\
(0.006)\end{array}$ & $\begin{array}{l}2.30^{* *} \\
0.044\end{array}$ & $\begin{array}{l}4.22 \\
(p=0.38)\end{array}$ \\
\hline & OLS & $\begin{array}{l}0.184^{* *} \\
(0.102)\end{array}$ & $\begin{array}{l}-0.0096 \\
(0.032)\end{array}$ & $\begin{array}{l}0.318 \\
(0.295)\end{array}$ & 0.32 \\
\hline
\end{tabular}

Note: Standard errors are reported in parentheses. The forward-looking model includes four lags for the inflation rate, the short-long spread, CPI rate, and M2 growth rate. ${ }^{*} \mathrm{p}<$ $0.05,{ }^{* *} \mathrm{p}<0.01,{ }^{* * *} \mathrm{p}<0.001$.

Source: Author's calculations. 


\subsubsection{The Yaqub² Regime 1993:Q3-1999:Q2}

Monetary policy under Yaqub was no different from that under his predecessors where inflation was concerned: the coefficient of the inflation rate in the forward-looking model is less than 1 (0.035 with SE 0.022) and the coefficient of the output gap is positive and significant but has a low value (0.0124 with SE 0.004). The p-value in the last column is high and, again, shows interest rate smoothing. The results of the backward-looking model are insignificant but the direction of monetary policy is the same. Under the Yaqub regime, therefore, the SBP preferred price stability to short-run growth since the coefficient of the inflation rate increased from 0.02 to 0.03 but did not fully adjust prices. The value of Rsquared reflects a less systematic monetary policy stance.

\subsubsection{The Husain Regime 1999:Q3-2005:Q3}

In the forward-looking model, the coefficient of the inflation rate is negative and insignificant (-0.0489 with SE 0.034) and the coefficient of the output gap, which measures sensitivity to the cyclical variable, is also insignificant. The interest rate smoothing value is low, showing interest rate inertia. As indicated by the low value of R-squared, the policy adopted was less active in achieving long-run price stability. The negative value for the output gap variable reflects a lack of commitment with respect to the short-run output gap in the economy.

\subsubsection{The Akhtar Regime 2005:Q4-2008:Q3}

Akhtar's regime was different from previous regimes in that it has the highest value of $p=0.93$. This implies considerable interest rate inertia although the coefficient of the inflation rate is low and significant. The output gap remains insignificant. The backward-looking model yields similar results. The high R-squared term shows that the Akhtar regime's monetary policy was systematic. However, the value of the inflation rate coefficient is less than 1 (0.162), which indicates a less aggressive policy. The output gap is negative and insignificant. The SBP's policy was, therefore, less active in attaining the goal of price stability and output gap, although the high value of R-squared implies an aggressively tight monetary policy.

\footnotetext{
${ }^{2}$ It is worth noting that, under President Leghari's caretaker regime in 1996, a committee was set up under Yaqub to review the State Bank of Pakistan Act, which changed the tenure of the governor from one five-year term to two three-year terms. While one five-year term allows the governor relative independence from the start of the tenure, the alternative makes the governor vulnerable insofar as he or she has to seek a second term.
} 


\subsubsection{The Present Regime 2008:Q4-2011:Q4}

In this case, the value of the inflation rate is still low but significant (0.011 with SE 0.003) and the output gap is negative and insignificant (0.009 with SE 0.006). The smoothing parameter is considerably high but lower than that under the Akhtar regime. In the backward-looking model, the inflation rate is less than 1 (0.184), implying there was no adjustment in the real interest rate and inflation rate. The output gap is negative, which confirms the use of an anti-cyclical policy. The low value of R-squared shows the policy was discretionary. Here, the monetary policy failed to control inflation and there was little adjustment between the interest rate and inflation rate. The output gap is negative, showing the lack of sensitivity to the cyclical variable.

The results of the forward-looking model indicate that monetary policy remained almost the same throughout the reform period (1989:Q12011:Q4). The coefficients of the inflation rate and output gap remain low. There is considerable interest rate inertia, confirming the interest ratesmoothing hypothesis, but the coefficient of the inflation rate remains low. Husain's period is characterized as chaotic, with insignificant coefficients with the wrong signs, and no interest rate smoothing.

\subsection{Chow Test Results: A Structural Break}

The Chow test is used to examine whether the interest rate for the inflation rate and output gap is the same before or after a specific regime or across various regimes. The test is applied to various SBP regimes to assess any differences in policy: 1993:Q3, 1999:Q3, 2005:Q4, and 2008:Q4. The results show that the coefficients are not stable across the Hanfi and Yaqub regimes, while the Hussain, Akhtar, and present regimes are structurally stable. A comparison of the backward-looking model and forward-looking model confirms the robustness of the results. In both cases, the signs and magnitudes of the parameters remain the same and consistent. The value of the inflation rate remains less than 1 for all regimes and the output gap switches from positive to negative for the present regime in both models.

On the whole, the SBP has always adopted inflationary policies but failed to adjust inflation with the real interest rate. Nominal interest rates have remained rigid in relation to the movement of the inflation rate. The low value of R-squared reflects a disordered policy stance, which can be attributed to incorrect estimates of the state of the economy. 
Akhtar adopted a tighter monetary stance that was organized but less active. This confirms that the SBP's monetary policy is backward looking and is not based on any particular rule. Commitment to policy will remain low if policymakers focus solely on their short-run aspirations.

\section{The Rules Path}

The Taylor rule demonstrates that a 2 percent inflation or interest rate is the best path available for safeguarding the output gap and inflation rate objective. Once we have fixed either the interest rate or the inflation rate at 2 percent, we can calculate the other as follows:

$$
\hat{\pi}^{*}=\frac{r^{*}-\hat{C}}{\hat{C}_{\pi}} \quad \hat{r}^{*}=\hat{C}+\hat{C}_{\pi} \pi^{*}
$$

The results in Table 4 show that the SBP has not followed any particular rule in determining the inflation rate or interest rate relationship other than a "rule of thumb." Further, there is no evidence of Taylor's "double duex" assumption of a 2 percent inflation or interest rate relationship in Pakistan. On average, the real interest rate has been very low - a reflection of the controlled financial market. The average inflation rate was 8.83 percent, which shows that price stability has not been seriously pursued by the SBP. One indication of this is that, under Hanfi and Akhtar, real interest rates were on the rise, not as a policy decision but because of the deteriorating fiscal situation in the economy.

Table 4: Implied interest rate and inflation targets

\begin{tabular}{lccccccc}
\hline Specification & & \multicolumn{1}{c}{$\mathbf{r}^{*} \Rightarrow \hat{\pi}^{*}$} & $\pi^{*} \Rightarrow \hat{r}^{*}$ & $\begin{array}{c}\text { Nominal } \\
\text { interest rate }\end{array}$ & $\begin{array}{c}\text { Actual } \\
\boldsymbol{\pi}\end{array}$ & $\begin{array}{c}\text { Real interest } \\
\text { rate }\end{array}$ \\
\hline 1971-2011 & 22 & -1.80 & 22 & -1.86 & 10.63 & 9.29 & 1.34 \\
1989:Q1-2011:Q1 & 22 & 0.37 & 22 & 12.94 & 11.97 & 9.09 & 2.89 \\
Hanfi & 22 & 0.311 & 22 & -71.4 & 10.00 & 9.57 & 0.425 \\
$\begin{array}{l}\text { 1989:Q1-1993:Q2 } \\
\text { Yaqub }\end{array}$ & 22 & -1.31 & 22 & 2.45 & 15.90 & 10.05 & 5.85 \\
$\begin{array}{l}\text { 1993:Q3-1999:Q2 } \\
\text { Husain }\end{array}$ & 22 & -1.88 & 22 & -2.58 & 9.68 & 4.78 & 4.90 \\
$\begin{array}{l}\text { 1999:Q3-2005:Q3 } \\
\text { Akhtar }\end{array}$ & 22 & 1.56 & 22 & -2.24 & 10.04 & 10.54 & -0.50 \\
$\begin{array}{l}\text { 2005:Q4-2008:Q3 } \\
\text { Present regime }\end{array}$ & 22 & -2.06 & 22 & -1.31 & 13.55 & 14.88 & -1.34 \\
2008:Q4-2011:Q4 & & & & & & & \\
\hline
\end{tabular}

Source: Author's calculations. 
If the inflation rate is targeted around an average inflation rate of 9 percent and the potential GDP growth rate also averages around its trend (5.4 percent during 1971-2011), the macroeconomic quadratic loss function can be estimated as follows:

$$
\text { Social Loss }=\left[2\left(\operatorname{Ln}\left(\pi-\pi^{*}\right)^{2}\right)+\operatorname{Ln}\left(q-q^{*}\right)^{2}\right]
$$

where $\left.\operatorname{Ln}\left(\pi-\pi^{*}\right)^{2}\right)$ denotes $\sigma^{2} \pi$ and $\operatorname{Ln}\left(q-q^{*}\right)^{2}$ denotes $\sigma^{2} y$.

Table 5 shows the social loss that results from keeping the interest rate lower than the optimal rate. In developing economies such as Pakistan, policymakers tend to argue that the interest rate must be kept low in order to maximize output, but this study shows that it increases the variability of inflation and output. The objective of interest rate smoothing and the low value of R-squared implies a less aggressive policy.

Table 5: Social loss 1971-2011

\begin{tabular}{lccc}
\hline Specification & $\boldsymbol{\sigma}^{\mathbf{2}} \boldsymbol{\boldsymbol { \sigma } ^ { \mathbf { 2 } } \boldsymbol { \pi }}$ & $\boldsymbol{S} \boldsymbol{L}=\boldsymbol{\sigma}^{\mathbf{2}} \boldsymbol{y}+\boldsymbol{\sigma}^{\mathbf{2}} \boldsymbol{\pi}$ \\
\hline 1971-2011 & 4.68 & 3.71 & 13.08 \\
1989:Q1-2011:Q1 & 4.35 & 1.22 & 9.93 \\
Hanfi 1989:Q1-1993:Q2 & 0.78 & 0.37 & 1.95 \\
Yaqub 1993:Q3-1999:Q2 & 2.36 & 0.38 & 5.09 \\
Husain 1999:Q3-2005:Q3 & 3.37 & 0.96 & 7.72 \\
Akhtar 2005:Q4-2008:Q3 & 10.95 & 0.69 & 22.58 \\
Present regime 2008:Q4-2011:Q4 & 2.51 & 0.26 & 5.28 \\
\hline
\end{tabular}

Source: Author's calculations.

\section{Conclusion}

Reforms in Pakistan's financial and monetary sector began in 1989. This paper provides empirical estimates of the rule-based monetary policy applied during the pre- and post-reform periods under different regimes at the SBP. We compare the effectiveness of this policy under backwardlooking as well as forward-looking reaction functions. We find that the inflation rate produced mixed results with growth, and that fiscal dominance made it difficult to pursue a discretionary monetary policy.

Our estimates indicate one minor difference between the pre- and post-reform periods. Generally, the monetary policy was characterized by a less aggressive response and was neither forward looking nor backward 
looking. In the pre-reform period, however, the SBP was less likely to raise the interest rate in response to an increase in inflation. In the postreform period, it was more likely to raise the interest rate in response to past inflation trends and expected inflation, but not to the extent of the required adjustment.

The results show that the Taylor-type rule does not explain interest rate adjustment in Pakistan over the period of study, given the inconsistencies we see in the interest rate and inflation rate. The SBP has not used a Taylor-type rule to maintain low inflation and stable output. Stable output is important in the short run to prevent future inflationary expectations. The structural break during the Hanfi and Yaqub regimes shows that their policies were different from those of their predecessors. Husain's regime generally accommodated the interest rate. Hanfi and Akhtar's regimes showed some convergence of the interest rate toward the real interest rate, although it remained below the actual real interest rate.

Overall, the SBP has not used the short-run interest rate to control long-run inflation and ensure stable output growth. Its policy stance reflects neither a forward-looking nor backward-looking model. The indeterminate relationship between the interest rate and inflation rate resulted in an output gap that has had social implications. An important implication for policy is that the SBP should use a modified rules-based approach to avoid fiscal dominance. 


\section{References}

Ahmad, N., \& Ahmed, F. (2006). The long-run and short-run endogeneity of money supply in Pakistan: An empirical investigation. State Bank of Pakistan Research Bulletin, 2(1), 267-278.

Bernanke, B. S., \& Woodford, M. (1997). Inflation forecasts and monetary policy. Journal of Money, Credit and Banking, 29(4), 653-684.

Buzeneca, I., \& Maino, R. (2007). Monetary policy implementation: Results from a survey (Working Paper No. 07/7). Washington, DC: International Monetary Fund.

Clarida, R., Galí, J., \& Gertler, M. (1997). Monetary policy rules and macroeconomic stability: Evidence and some theory (Working Paper No. 350). Barcelona, Spain: Universitat Pompeu Fabra, Department of Economics and Business.

Clarida, R., Galí, J., \& Gertler, M. (1998). Monetary policy rules in practice: Some international evidence. European Economic Review, 42(6), 1033-1067.

Clarida, R., Galí, J., \& Gertler, M. (2000). Monetary policy rules and macroeconomic stability: Evidence and some theory. Quarterly Journal of Economics, 115(1), 147-180.

Friedman, M. (1977). Nobel lecture: Inflation and unemployment. Journal of Political Economy, 85(3), 451-472.

Goodhart, C. (1984). Monetary theory and practice. London, UK: Macmillan.

Goodhart, C. (1991). The conduct of monetary policy. In C. Green \& D. Llewellyn (Eds.), Surveys in monetary economics (vol. 1): Monetary theory and policy. Oxford, UK: Blackwell

Hansen, L. P. (1982). Large sample properties of generalized methods of moments estimators. Econometrica, 50(4), 1029-1054.

Harvey, A. C., \& Jaeger, A. (1993). Detrending, stylized facts and the business cycle. Journal of Applied Econometrics, 8(3), 231-247.

Harvey, A. C., \& Trimbur, T. (2008). Trend estimation and the HodrickPrescott filter. Journal of the Japan Statistical Society, 38(1), 41-49. 
International Monetary Fund. (2011). International financial statistics. Washington, DC: Author.

Janjua, M. A. (2004). History of the State Bank of Pakistan 1988-2003. Karachi, Pakistan: State Bank of Pakistan.

Kerr, W., \& King, R. G. (1996). Limits on interest rate rules in the IS model. Federal Reserve Bank of Richmond Economic Quarterly, 82(2), 47-76.

Khan, M. S., \& Schimmelpfennig, A. (2006). Inflation in Pakistan: Money or wheat? (Working Paper No. 06/60). Washington, DC: International Monetary Fund.

Malik, W. S., \& Ahmed, A. M. (2010). Taylor rule and the macroeconomic performance in Pakistan. Pakistan Development Review, 49(1), 37-56.

Mishkin, F. S. (1996). Understanding financial crises: A developing country perspective. In M. Bruno \& B. Pleskovic (Eds.), Annual World Bank Conference on Development Economics (pp. 29-62). Washington, DC: World Bank.

Nell, K. S. (2000/01). The endogenous/exogenous nature of South Africa's money supply under direct and indirect monetary control measures. Journal of Post Keynesian Economics, 23(2), 313-329.

Orphanides, A., \& Wieland, V. (2013). Complexity and monetary policy. International Journal of Central Banking, 9, 167-203.

Ravn, M. O., \& Uhlig, H. (2002). On adjusting the Hodrick-Prescott filter for the frequency of observations. Review of Economics and Statistics, 84(2), 371-375.

Roodman, D. (2009). Practitioners' corner: A note on the theme of too many instruments. Oxford Bulletin of Economics and Statistics, 71(1), 135-158.

Rudebusch, G. D. (2002). Term structure evidence on interest rate smoothing and monetary policy inertia. Journal of Monetary Economics, 49(6), 1161-1187.

Shanmugam, B., Nair, M., \& Li, O. W. (2003). The endogenous money hypothesis: Empirical evidence from Malaysia (1985-2000). Journal of Post Keynesian Economics, 25(4), 599-611. 
State Bank of Pakistan. (n.d.). Governor's speeches. Retrieved from http://www.sbp.org.pk/about/speech/

State Bank of Pakistan. (2009). Pakistan ten-year strategy paper for the banking sector reforms. Retrieved from http://www.sbp.org.pk/bsd/ 10YearStrategyPaper.pdf

Taylor, J. B. (1993a). Discretion versus policy rules in practice. CarnegieRochester Conference Series on Public Policy, 39, 195-214.

Taylor, J. B. (1993b). Macroeconomic policy in a world economy: From econometric design to practical operation. New York, NY: W. W. Norton.

Taylor, J. B. (1999a). An historical analysis of monetary policy rules. In J. B. Taylor (Ed.), Monetary policy rules, 319-348. Chicago, IL: University of Chicago Press.

Taylor, J. B. (Ed.). (1999b). Monetary policy rules. Chicago, IL: University of Chicago Press.

Taylor, J. B. (2000). Low inflation, pass-through, and the pricing power of firms. European Economic Review, 44(7), 1389-1408.

Taylor, J. B. (2001). Using monetary policy rules in emerging market economies. In Stabilization and monetary policy: The international experience. Mexico City: Banco de México.

Tchaidze R. R. (2001). Estimating Taylor rules in a real time setting (Working Paper No. 457). Baltimore, MD: Johns Hopkins University.

Woodford, M. (2000). Pitfalls of forward-looking monetary policy. American Economic Review, 90(2), 100-104.

Woodford, M. (2001). The Taylor rule and optimal monetary policy. American Economic Review, 91(2), 232-237. 


\section{Appendix}

Chow forecast test: Predictions for observations from 1993

\begin{tabular}{llll}
\hline F-statistic & 2.597698 & Prob. F $(3,34)$ & 0.0600 \\
Log likelihood ratio & 8.254823 & Prob. chi-square (3) & 0.0410 \\
Wald statistic & 7.793094 & Prob. chi-square (3) & 0.0505 \\
\hline
\end{tabular}

Test predictions for observations from 1993 to 2010

\begin{tabular}{lccc}
\hline & Value & Df & Probability \\
\hline F-statistic & 20.95344 & $(18,19)$ & 0.0000 \\
Likelihood ratio & 121.4954 & 18 & 0.0000 \\
\hline
\end{tabular}

\section{F-test summary}

\begin{tabular}{lccc}
\hline & Sum of squares & Df & Mean squares \\
\hline Test SSR & 107.0749 & 18 & 5.948607 \\
Restricted SSR & 112.4690 & 37 & 3.039701 \\
Unrestricted SSR & 5.394033 & 19 & 0.283896 \\
Unrestricted SSR & 5.394033 & 19 & 0.283896 \\
\hline
\end{tabular}

LR summary test

\begin{tabular}{lcl}
\hline & Value & Df \\
\hline Restricted $\log \mathrm{L}$ & -77.43350 & 37 \\
Unrestricted $\log \mathrm{L}$ & -16.68582 & 19 \\
\hline
\end{tabular}

Unrestricted log likelihood adjusts test equation

\begin{tabular}{lccc}
\hline Variable & Coefficient & Std. error & t-statistic \\
\hline C & 0.505661 & 0.259490 & 1.948676 \\
D (DEF) & -0.222812 & 0.178928 & -1.245264 \\
D (YGAP) & 0.001393 & 0.005277 & 0.263974 \\
R-squared & 0.080087 & Mean dependent var. & 0.227273 \\
Adjusted R-squared & -0.016745 & SD dependent var. & 0.528413 \\
SE of regression & 0.532819 & Akaike info criterion & 1.704855 \\
Sum squared residual & 5.394033 & Schwarz criterion & 1.853634 \\
Log likelihood & -15.75341 & Hannan-Quinn criterion & 1.739903 \\
F-statistic & 0.827068 & Durbin-Watson stat. & 1.114722 \\
\hline
\end{tabular}




\section{Quarterly data: Chow breakpoint test}

Equation sample: 1989:Q1-2011:Q4

\begin{tabular}{llll}
\hline F-statistic & 3.860546 & Prob. F $(3,83)$ & 0.0122 \\
Log likelihood ratio & 11.62542 & Prob. chi-square (3) & 0.0088 \\
Wald statistic & 11.58164 & Prob. chi-square (3) & 0.0090 \\
\hline
\end{tabular}

Equation sample: 1999:Q3

\begin{tabular}{llll}
\hline F-statistic & 5.983896 & Prob. F $(3,83)$ & 0.0010 \\
Log likelihood ratio & 17.42633 & Prob. chi-square (3) & 0.0006 \\
Wald statistic & 17.95169 & Prob. chi-square (3) & 0.0005 \\
\hline
\end{tabular}

Equation sample: 2005:Q3

\begin{tabular}{llll}
\hline F-statistic & 2.437183 & Prob. F $(3,83)$ & 0.0704 \\
Log likelihood ratio & 7.513802 & Prob. chi-square (3) & 0.0572 \\
Wald statistic & 7.311549 & Prob. chi-square (3) & 0.0626 \\
\hline
\end{tabular}

Equation sample: 2008:Q4

\begin{tabular}{llll}
\hline F-statistic & 0.025386 & Prob. F $(3,83)$ & 0.9945 \\
Log likelihood ratio & 0.081625 & Prob. chi-square (3) & 0.9939 \\
Wald statistic & 0.076157 & Prob. chi-square (3) & 0.9945 \\
\hline
\end{tabular}

